\title{
Karakteristik Tiwul Instan Subtitusi Ubi Jalar Kuning (Ipomoea batatas L.) sebagai Sumber $\beta$-Karoten
}

\author{
Properties of Instant Tiwul Subtitution of Yellow Sweet Potato (Ipomoea batatas L.) as Source of $\beta$-Carotene \\ Herlina Herlina*, Syaiful Adzim, Ahmad Nafi, Nita Kuswardhani \\ Jurusan Teknologi Hasil Pertanian, Fakultas Teknologi Pertanian, Universitas Jember, \\ Jl. Kalimantan No. 37 Jember, 68121, Jawa Timur, Indonesia \\ *Penulis korespondensi: Herlina, Email: lina.ftp@unej.ac.id
}

Tanggal submisi: 19 Februari 2019; Tanggal revisi: 18 Mei 2020; Tanggal penerimaan: 19 Juni 2020

\begin{abstract}
ABSTRAK
Tujuan penelitian ini adalah mempelajari pengaruh persentase subtitusi ubi jalar kuning (Ipomoea batatas L.) terhadap karakteristik fisik, kimia dan organoleptik tiwul instan dan menentukan persentase ubi jalar kuning yang tepat sehingga dihasilkan tiwul instan dengan kandungan $\beta$-karoten tinggi dan disukai panelis. Metode penelitian ini menggunakan Rancangan Acak Lengkap (RAL) dengan faktor tunggal, yaitu persentase subtitusi ubi jalar kuning $(0 ; 10 ; 20 ; 30 ; 40 ;$ dan 50\%). Setiap perlakuan dilakukan ulangan sebanyak 3 (tiga) kali ulangan, data yang diperoleh dianalisis menggunakan uji analysis of variance (ANOVA), dan apabila ada perbedaan yang nyata antar perlakuan $(a \leq 0,05)$ dilanjutkan dengan uji beda duncan new multiple range test (DNMRT), sedangkan data organoleptik diuji menggunakan uji chi-square $(a \leq 0,05)$, dan untuk menentukan perlakuan terbaik dilakukan uji efektivitas. Hasil penelitian menunjukkan bahwa persentase subtitusi ubi jalar kuning berpengaruh nyata terhadap kadar air, jumlah total $\beta$-karoten, daya rehidrasi, daya kembang, densitas kamba, kesukaan panelis akan warna, aroma, rasa, tekstur, kekenyalan dan keseluruhan $(a \leq 0,05)$. Berdasarkan uji efektivitas didapatkan persentase subtitusi ubi jalar kuning yang tepat pada pembuatan tiwul instan adalah pada perlakuan P3 (subtitusi ubi jalar kuning sebesar 30\%), yang memiliki kandungan total $\beta$-karoten sebesar 0,336 mg/100 $\mathrm{g}$, kesukaan panelis akan warna, aroma, rasa, tekstur, kekenyalan, dan keseluruhan, berturut-turut adalah 28, $32,40,32,36$, dan $32 \%$.
\end{abstract}

Kata kunci: $\beta$ - karoten; uji efektivitas; tiwul instan; ubi jalar kuning

\begin{abstract}
This study aims to examine the effect of percentage substitute of yellow sweet potato (Ipomoea batatas L.) on the physical, chemical and organoleptic characteristics of instant tiwul. It also aims to determine the exact percentage of yellow sweet potato in instant tiwul with high $\beta$-carotene content and favored by panelists. The completely randomized design (CRD) method was used with a single factor, namely the percentage substitution of yellow sweet potato $(0,10,20,30,40$, and $50 \%$ ). Each treatment was repeated 3 (three) times while the data obtained were analyzed using the analysis of variance (ANOVA). In addition, when significant differences exist
\end{abstract}


between treatments ( $a \leq 0,05$ ), the Duncan new multiple range test (DNMRT) is used, organoleptic data were analyzed using the chi-square test ( $a \leq 0.05$ ), meanwhile, to determine the best treatment, an effectiveness test was performed. The results showed that the percentage substitution of yellow sweet potato significantly affected the water content, total $\beta$-carotene content, rehydration and swelling power, bulk density, panelists' preference for color, aroma, taste, texture, elasticity and overall. Based on the effectiveness test, the best percentage substitution of yellow sweet potato in instant tiwul production was P3 treatment (yellow sweet potato substitution by $30 \%$ ), which has a total $\beta$-carotene content of $0.336 \mathrm{mg} / 100 \mathrm{~g}$, panelists' preference for color, aroma, taste, texture, suppleness, and overall of $28,32,40,32,36$, and $32 \%$ respectively.

Keywords: $\beta$ - carotene; effectiveness test; Instant tiwul; yellow sweet potato

\section{PENDAHULUAN}

Permasalahan nasional dibidang pangan semakin komplek seiring dengan peningkatan jumlah penduduk dan pola kehidupan modern. Penyediaan pangan yang murah dan sehat serta memenuhi selera masyarakat modern semakin dibutuhkan, terutama makanan kaya zat gizi dan menyehatkan. Laporan BPPK (2010), berdasarkan penelitian riset kesehatan dasar (RISKESDAS) menunjukkan bahwa penduduk Indonesia yang usianya di atas 18 tahun memiliki status gizi kurang sebanyak $12,6 \%$.

Pola makan atau diet merupakan faktor utama dalam menentukan seseorang mengalami gizi kurang atau gizi lebih. Untuk penderita gizi kurang diet mempunyai tujuan guna memenuhi kebutuhan energi tubuh, mencegah kerusakan jaringan dan mendapatkan berat badan normal atau ideal, sedangkan diet bagi penderita gizi lebih bertujuan menyesuaikan status gizi sesuai dengan umur, jenis kelamin, kebutuhan fisik untuk mendapatkan indeks massa tubuh (IMT) ideal/ normal, yaitu sebesar 18,5-25 kg/m² (Almatsier, 2010).

Pangan alternatif yang sangat potensial dikembangkan di Indonesia adalah ubi kayu atau singkong (Monihot uttilisima L.). Menurut Soetanto (2008) Di Indonesia singkong merupakan makanan pokok ke tiga setelah padi dan jagung. Perkembangan produktivitas singkong di Indonesia selama 5 (lima) tahun, yaitu mulai tahun 2011 sampai tahun 2015 mengalami peningkatan sebesar $3,84 \%$, dengan ratarata luas panen singkong di tiga provinsi sentra tanaman singkong, yaitu provinsi Lampung, Jawa Timur, dan Jawa Tengah berturut-turut sebesar 30,11\%; 16,04\% dan 15,17\% (Badan Pusat Statistik, 2016).

Kondisi di lapang saat ini tanaman singkong hampir di tanam di seluruh wilayah Indonesia, pada waktu singkong mengalami panen raya singkong segar tidak dapat di simpan dalam waktu lama, masa simpan singkong berkisar antara 4-5 hari, selebihnya singkong akan mengalami penurunan kualitas yaitu umbinya berubah menjadi biru atau hitam (Soetanto, 2008). Di beberapa daerah seperti di wilayah provinsi
Jawa Timur dan Jawa Tengah, serta Yogyakarta untuk mengatasi umbi singkong yang mudah rusak diatasi dengan diversifikasi pembuatan produk olahan pangan berbasis singkong, yaitu tiwul, gatot, keripik singkong, kerupuk samiler, tepung singkong modifikasi (MOCAF), dan tapioka.

Tiwul merupakan salah satu makanan tradisional yang saat ini sangat digemari masyarakat sebagai pangan alternatif pengganti nasi, tiwul terbuat dari tepung singkong yang di kukus ditambah gula kelapa dan penyajiannya dengan kelapa parut. Pembuatan tepung singkong dapat dibuat secara tradisional (gaplek) atau secara fermentasi spontan yang dikenal dengan tepung MOCAF (Modified Cassava Flour) (Putri dkk., 2018). Ditinjau dari bahan bakunya tiwul merupakan jenis makanan kaya karbohidrat dan miskin kandungan gizi yang lain. Untuk mempromosikan tiwul sebagai pangan alternatif pengganti beras dan gandum yang dapat menopang ketahanan pangan di Indonesia maka diperlukan solusi untuk mensubtitusi bahan baku tiwul dengan bahan lain yang mempunyai nilai gizi tinggi, salah satu alternatif adalah disubtitusi dengan ubi jalar kuning (Ipomoea batatas L.) yang kaya $\beta$-karoten dan antioksidan alami (Dwiyanti dkk., 2018). Selain itu perkembangan produk tiwul sebagai pangan alternatif pengganti nasi untuk masyarakat belum berkembang, hal ini juga disebabkan karena proses pembuatan tiwul memerlukan waktu yang cukup lama dan tahapan proses yang panjang sehingga masyarakat tidak tertarik untuk mengkonsumsi tiwul. Berdasarkan kondisi tersebut diperlukan rekayasa produk pengolahan tiwul menjadi tiwul instan, sehigga masyarakat lebih praktis dalam penyajian tiwul.

Ubi jalar kuning mengandung antosianin dan $\beta$-karoten, kandungan antosianin pada ubi jalar kuning segar sebesar 519 mg/100g (Kano dkk., 2005), dan aktivitas antioksidannya sebesar 97,92\% (Dwiyanti dkk., 2018). Menurut Yoshimoto dkk. (2001) antosianin pada ubi jalar kuning merupakan antioksidan alami dan penangkal radikal bebas serta mempunyai stabilitas yang tinggi terhadap suhu dan $\mathrm{pH}$. Antioksidan pada ubi jalar kuning mengandung vitamin $\mathrm{C}$ yang cukup 
tinggi (Harada dkk., 2004). Kandungan $\beta$-karoten pada ubi jalar kuning sebesar $2900 \mu \mathrm{g} / 100 \mathrm{~g}$, $\beta$-koroten merupakan salah satu karotenoid yaitu provitamin A yang sangat maik untuk memelihara kesehatan mata (Thompson dkk., 2011). Berdasarkan permasalahan di atas perlu dilakukannya penelitian tentang pengaruh persentase subtitusi ubi jalar kuning terhadap karakteristik fisik, kimia dan organoleptik tiwul instan dengan subtitusi ubi jalar kuning sebagai sumber $\beta$-karoten dan menentukan persestase ubi jalar kuning yang tepat sehingga dihasilkan tiwul instan dengan $\beta$-karoten tinggi yang disukai.

\section{METODE PENELITIAN}

\section{Bahan dan Alat}

Bahan yang digunakan dalam penelitian ini adalah singkong dan ubi jalar kuning diperoleh dari desa Pakis, kecamatan Panti, kabupaten Jember, provinsi Jawa Timur, gula kristal putih merk gulaku, garam, air, kalium dikromat, etanol $97 \%$, dan aquades.

Alat yang digunakan dalam penelitian ini adalah oven (Blower Excellent 53L UFE400), eksikator (Lokal $21 \mathrm{~cm}$ ), vortex (IKA), tabung reaksi (Pyrex $20 \mathrm{ml}$ ), spektrofotometer Genesys 10S UV-VIS, ayakan 80 mesh (Sieve), kompor (Rinnai RI-522E), colour reader Konica Minolta CR-10 Jepang, beaker glass (Duran), gelas ukur (Shagufta), pisau (Stainless Lokal), dandang (Aluminium Lokal), penjepit, grinder, sendok, neraca analitik Ohaus BSA 2245, timbangan (Sigma Type SM 6000 ), kertas saring (Whatman 42), dan vortex Max Mix 1 Type 16700.

\section{Pembuatan Tepung Singkong (Soetanto, 2008)}

Singkong segar dikupas untuk dipisahkan antara kulit dengan daging singkong, dilanjutkan dengan pencucian untuk membersihkan sisa-sisa kotoran pada daging singkong. Danging singkong yang telah bersih kemudian dilakukan pemotongan berbentuk chip (ketebalan $\pm 2 \mathrm{~mm}$ ), pemotongan bertujuan untuk mempermudah proses pengeringan. Setelah terbentuk chip dilakukan perendaman dengan menggunakan air bersih dengan persentase rasio chip singkong : air (1:2) selama 12 jam, hal ini bertujuan untuk mengurangi kadar asam sianida pada singkong. Chip yang direndam kemudian dilakukan penirisan dan penjemuran dibawah sinar matahari selama \pm 6 jam. Langkah selanjutnya dilakukan pengeringan menggunakan oven vakum pada suhu $\pm 60^{\circ} \mathrm{C}$ selama 8 jam. Chip yang sudah kering digiling menggunakan grinder, yang dilanjutkan dengan proses pengayakan menggunakan ayakan 80 mesh.

\section{Pembuatan Bubur Ubi Jalar Kuning (Suprapti, 2003)}

Ubi jalar kuning segar dikupas untuk memisahkan antara kulit dan daging umbi, kemudian dilakukan pencucian untuk menghilangkan kotoran yang menempel pada daging umbi. Selanjutnya dilakukan pengukusan hingga umbi matang secara maksimal (suhu $100{ }^{\circ} \mathrm{C}$, selama \pm 45 menit). Kemudian didinginkan dan umbi dihancurkan atau dilumatkan dengan alat pelumat hingga menjadi bubur/lumatan ubi jalar kuning.

\section{Pembuatan Tiwul Instan Subtitusi Ubi Jalar Kuning (Rukmini dan Naufalin, 2015)}

Pembuatan tiwul instan dengan subtitusi ubi jalar kuning dimulai dengan pencampuran bahan yaitu tepung singkong (100; 90; 80; 70; 60; dan 50\%) dan bubur ubi jalar $(0 ; 10 ; 20 ; 30 ; 40$; dan $50 \%)$, gula $5 \%$, garam $1 \%$ dan air $20 \%$ dan diaduk hingga homogen. Proses selanjutnya adalah pengukusan adonan yang telah tercampur selama \pm 45 menit, pengukusan bertujuan untuk membuat tiwul menjadi matang. Kemudian tiwul di dinginkan dan dilakukan pencetakan menggunakan ekstruder yang bertujuan untuk menyeragamkan bentuk, dilanjutkan dengan pengeringan menggunakan oven dengan suhu $55^{\circ} \mathrm{C}$ selama 9 jam hingga tiwul instan benar-benar kering sehingga tiwul instan memiliki umur simpan yang cukup lama.

\section{Rancangan Percobaan dan Analisis Data}

Penelitian ini dilaksanakan dengan rancangan acak lengkap (RAL) faktor tunggal yaitu $\mathrm{P}=$ persentase subtitusi bubur ubi jalar kuning dan setiap perlakuan diulang 3 (tiga). Secara rinci perlakuan dalam penelitian ini adalah P0 $=0 \%$ bubur ubi jalar kuning $+100 \%$ tepung singkong, $\mathrm{P} 1=10 \%$ bubur ubi jalar kuning + $90 \%$ tepung singkong, $\mathrm{P} 2=20 \%$ bubur ubi jalar kuning $+80 \%$ tepung singkong, $\mathrm{P} 3=30 \%$ bubur ubi jalar kuning $+70 \%$ tepung singkong, $\mathrm{P} 4=40 \%$ bubur ubi jalar kuning $+60 \%$ tepung singkong, dan P5 $=50 \%$ bubur ubi jalar kuning $+50 \%$ tepung singkong.

\section{Parameter Pengamatan}

Parameter pengamatan meliputi pengamatan fisik, kimia, dan organoleptik serta uji efektivitas. Pengamatan fisik meliputi daya rehidrasi, daya kembang, densitas kamba, dan kecerahan warna (Romlah dan Haryadi, 1997). Pengamatan kimia meliputi kadar air (AOAC, 2007) dan uji kandungan $\beta$-karoten (Pujimulyani dan Wazyka, 2009). Uji kesukaan/hedonik secara organoleptik meliputi kesukaan warna, aroma, rasa, tekstur, kekenyalan, dan keseluruhan dengan cara 
hedonic scale scoring yang mana penelis diminta untuk menentukan nilai kesukaan produk dengan memberi nilai produk kisaran nilainya sudah ditentukan (Mabesa, 1986).

\section{Analisis Data}

Data hasil dari pengujian sifat fisik dan kimia akan dianalisis menggunakan ANOVA dan jika antar perlakuan diperoleh perbedaan yang nyata/signifikan $(a \leq 0,05)$, dilanjutkan dengan uji beda DNMRT. Data hasil pengujian organoleptik dianalisis dengan menggunakan uji chi-square. Sedangkan untuk menentukan perlakuan terbaik diuji menggunakan uji efektivitas (DeGarmo dkk., 1984).

\section{HASIL DAN PEMBAHASAN}

\section{Daya Rehidrasi}

Berdasarkan hasil penelitian yang telah dilakukan, dapat diketahui bahwa nilai rata-rata daya rehidrasi tiwul instan pada berbagai persentase subtitusi ubi jalar kuning berkisar antara 3,69-4,73\% (Gambar 1) yang artinya tiwul instan memiliki daya rehidrasi 3-4 kali lipat dari berat bahan. Hasil sidik ragam taraf nyata $(a \leq 0,05)$ menunjukkan bahwa persentase subtitusi ubi jalar kuning pada tiwul instan berpengaruh nyata terhadap daya rehidrasi tiwul instan sehingga dilanjutkan dengan uji DNMRT.

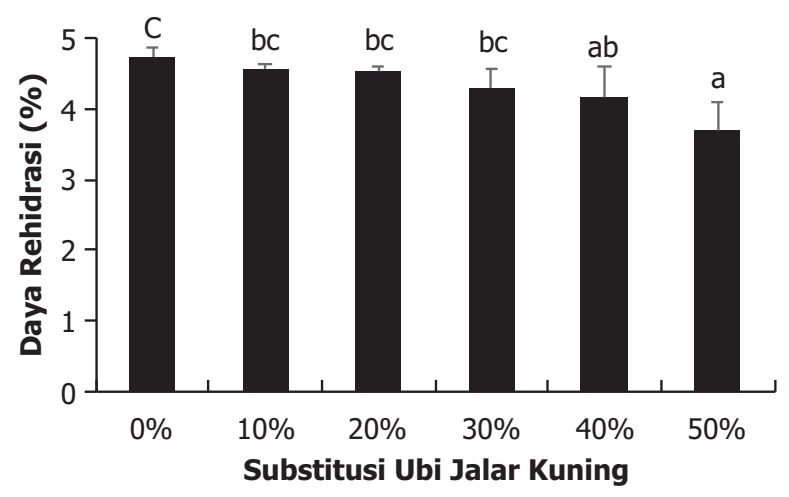

Keterangan:

Huruf yang sama pada histogram menunjukkan berbeda tidak nyata pada uji anova $(a \leq 0,05)$.

Gambar 1. Grafik daya rehidrasi tiwul instan pada berbagai persentase subtitusi ubi jalar kuning

Berdasarkan Gambar 1 dapat diketahui bahwa daya rehidrasi tiwul instan tertinggi diperoleh pada perlakuan subtitusi ubi jalar kuning $0 \%$ dengan nilai $4,73 \%$, sedangkan nilai terendah diperoleh pada perlakuan subtitusi ubi jalar kuning sebesar $50 \%$ dengan nilai 3,69\%, dapat diketahui bahwa semakin tinggi persentase subtitusi ubi jalar kuning maka daya rehidrasi yang dihasilkan akan semakin rendah, hal tersebut dipengaruhi oleh kandungan pati dan amilosa. Kandungan pati singkong sebesar $81 \%$ (Subagio, 2006) lebih tinggi dibandingan kandungan pati ubi jalar yaitu 32\% (Balitkabi, 2009).

Daya rehidrasi produk berpati sangat ditentukan oleh kandungan amilosanya, semakin tinggi kandungan amilosa maka semakin tinggi daya rehidrasi produk. Hal tersebut berkaitan dengan peningkatan jumlah gugus hidrofilik yang memiliki kemampuan menyerap air lebih besar (Harada dkk., 2004). Menurunnya daya rehidrasi disebabkan oleh semakin meningkatnya subtitusi ubi jalar kuning kedalam tiwul instan dan jumlah tepung singkong yang semakin sedikit. Kandungan amilosa ubi jalar lebih kecil antara 15-25\% (Putri, 2015) dibanding kandungan amilosa tepung singkong yaitu 27,5\% (Murtiningrum dkk., 2016).

\section{Densitas Kamba}

Berdasarkan hasil penelitian yang telah dilakukan dapat diketahui bahwa nilai rata-rata densitas kamba tiwul instan pada berbagai persentase subtitusi ubi jalar kuning berkisar antara 0,40-0,43 g/mL (Gambar 2). Hasil sidik ragam taraf nyata $(a \leq 0,05)$ menunjukkan bahwa persestase subtitusi ubi jalar kuning pada tiwul instan berpengaruh nyata terhadap densitas kamba tiwul instan sehingga dilanjutkan uji DNMRT.

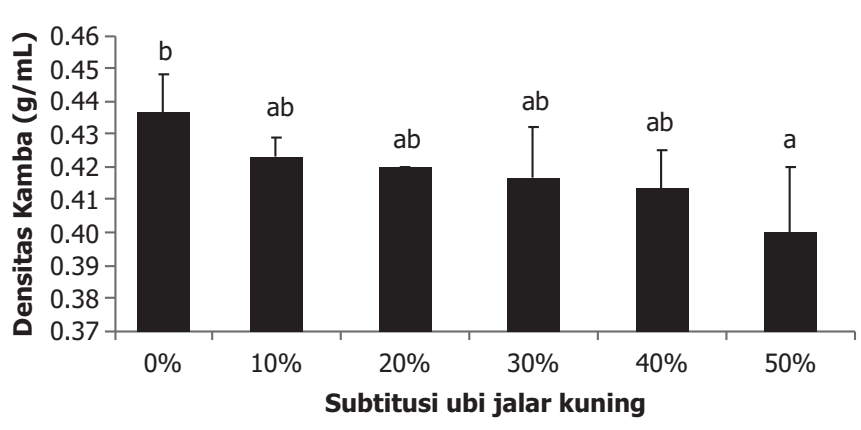

Keterangan:

Huruf yang sama pada histogram menunjukkan berbeda tidak nyata pada uji anova $(a \leq 0,05)$

Gambar 2. Grafik densitas kamba tiwul instan pada berbagai persentase subtitusi ubi jalar kuning

Berdasarkan Gambar 2 diketahui bahwa densitas kamba tiwul instan dengan subtitusi ubi jalar kuning tertinggi diperoleh pada perlakuan persentase ubi jalar kuning $0 \%$ dengan nilai sebesar $0,43 \mathrm{~g} / \mathrm{mL}$, sedangkan nilai terendah diperoleh pada perlakuan persentase 
subtitusi ubi jalar kuning $50 \%$ sebesar $0,40 \mathrm{~g} / \mathrm{mL}$. Nilai densitas kamba berbanding terbalik dengan jumlah subtitusi ubi jalar kuning, semakin tinggi subtitusi ubi jalar kuning maka nilai densitas kamba akan semakin kecil. Husain dkk. (2006) menyatkan bahwa densitas kamba dipengaruhi oleh kadar air bahan, semakin rendah kadar air maka densitas kamba akan semakin besar, hal ini sesuai dengan kadar air tiwul instan yang dihasilkan, yaitu kadar air perlakuan persentase subtitusi ubi jalar kuning $0 \%$ dan $50 \%$ adalah $4,74 \%$ dan 7,88\% (Gambar 5).

Tingginya kandungan air bahan menyebabkan terbentuknya partikel yang semakin besar disebabkan oleh air yang terperangkap oleh granula pati sehingga bahan semakin porous, dengan tingginya kandungan air maka granula yang terbentuk akan semakin besar dan densitas kamba yang dihasilkan akan semakin kecil. Semakin tinggi kadar air tiwul instan, maka densitas kamba yang dihasilkan akan semakin kecil dan ruang penyimpanan yang digunakan semakin besar. Faktor-faktor yang mempengaruhi densitas kamba yaitu karakteristik ukuran partikel atau granula, ruang kosong (void) dan porositas. Karakteristik ukuran granula diantaranya adalah pipih, bulat, beratutan atau tidak, kecil, besar homogennya granula bahan tersebut (Heldman \& singh 1981).

\section{Daya Kembang}

Berdasarkan hasil penelitian yang telah dilakukan dapat diketahui bahwa nilai rata-rata daya kembang tiwul instan dengan subtitusi ubi jalar kuning berkisar antara 34,33-42,33\% (Gambar 3). Hasil sidik ragam taraf nyata $(a \leq 0,05)$ menunjukkan bahwa persentase subtitusi ubi jalar kuning pada tiwul instan berpengaruh nyata terhadap daya kembang tiwul instan sehingga dilanjutkan dengan uji DNMRT.

Berdasarkan Gambar 3 dapat diketahui bahwa yang memiliki nilai daya kembang tertinggi yaitu pada perlakuan persentase ubi jalar kuning $0 \%$ sebesar $42,33 \%$ dan nilai daya kembang terendah diperoleh pada perlakuan persentase subtitusi ubi jalar kuning sebesar $50 \%$ sebesar $34,33 \%$. Hal tersebut disebabkan oleh semakin berkurangnya jumlah tepung singkong yang digunakan, pada tepung singkong terdapat kandungan amilopektin yang lebih tinggi dibandingkan amilosa. Amilopektin yang tinggi menyebabakan tiwul instan menjadi lebih tinggi daya kembangnya. Hartati dan Prana (2003), menyatakan bahwa sifat dari pati dalam produk pangan berpati yang sangat berpengaruh terhadap daya kembang adalah amilopektin karena amilopektin berpengaruh terhadap swelling properties (Swinkels \& Veendams, 1985).

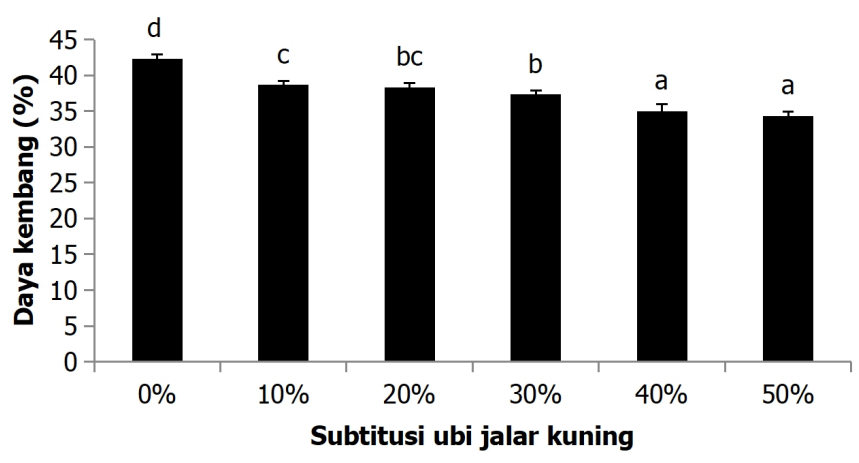

Keterangan:

Huruf yang sama pada histogram menunjukkan berbeda tidak nyata pada uji anova ( $a \leq 0,05)$

Gambar 3. Grafik daya kembang tiwul instan pada berbagai persentase subtitusi ubi jalar kuning

Daya kembang produk berpati dipengaruhi oleh komposisi rasio amilosa : amilopektin, distribusi berat molekul dan panjang rantai atom (Bemiller \& Whistler, 1996). Kandungan amilosa yang tinggi bersifat lebih kering, tidak lengket dan menyerap air atau higroskopis, sedangkan daya kembang merupakan sifat yang dipengaruhi oleh kandungan amilopektin (Moorthy, 2004). Kandungan amilopektin tepung singkong $72,62 \%$ dari jumlah pati sebesar $80 \%$ lebih tinggi dari pada kandungan amilopektin ubi jalar yaitu $80 \%$ dari total pati sebesar 32\% (Murtiningrum, 2012).

\section{Tingkat Kecerahan Warna (Lightness)}

Berdasarkan penelitian yang telah dilakukan dapat diketahui rata-rata tingkat kecerahan warna tiwul instan pada berbagai persentase subtitusi ubi jalar kuning berkisar antara 51,42-72,68 (Gambar 4). Hasil sidik ragam taraf nyata $(a \leq 0,05)$ menunjukkan bahwa variasi persentase subtitusi ubi jalar kuning pada tiwul instan berpengaruh nyata terhadap tingkat kecerahan warna tiwul instan sehingga dilanjutkan dengan uji DMRT.

Berdasarkan Gambar 4 dapat diketahui bahwa subtitusi ubi jalar kuning dapat mempengaruhi tingkat kecerahan warna tiwul instan, nilai tertinggi diperoleh pada perlakuan persentase ubi jalar kuning $0 \%$ dengan nilai 72,68 , dan nilai terendah diperoleh pada perlakuan persentase subtitusi ubi jalar kuning 50\% dengan nilai 51,42 . Perubahan tersebut disebabkan oleh sifat fisik bahan utama yaitu ubi jalar kuning yang memiliki kenampakan warna kuning, sehingga mampu mempengaruhi produk akhir tiwul instan. Menurut Hidayat dan Saati (2006), bahwa karotenoid menghasilkan warna jingga sampai merah. Maka 


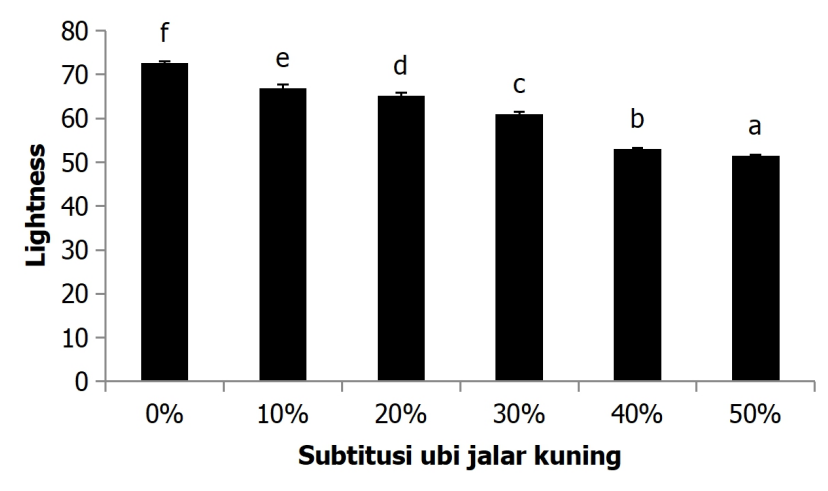

Keterangan:

Huruf yang sama pada histogram menunjukkan berbeda tidak nyata pada uji anova $(a \leq 0,05)$

Gambar 4. Grafik kecerahan warna tiwul instan pada berbagai persentase subtitusi ubi jalar kuning

semakin tinggi subtitusi ubi jalar kuning warna tiwul instan yang dihasilkan akan semakin gelap.

Kecerahan warna tiwul yang dihasilkan juga disebabkan oleh perubahan selama proses pembuatan, proses pembuatan tiwul yang melibatkan gula pereduksi dan gugus amin yang dipicu oleh adanya pemanasan sehingga terbentuk pigmen melanoidin yang bertanggung jawab pada pembentukan warna lebih gelap (Kusnandar, 2010). Proses inilah yang disebut dengan reaksi maillard, reaksi ini dipengaruhi oleh suhu, konsentrasi gula, konsentrasi amino, $\mathrm{pH}$, dan tipe gula (Benyamin, 2012). Menurut Bradbury dan Nixon (1998), ubi jalar mengandung gula sebesar 2,38\%, semakin tinggi kandungan gula pada bahan maka reaksi maillard juga akan besar yang mengakibatkan perubahan warna semakin besar.

\section{Kadar Air}

Berdasarkan hasil penelitian yang telah dilakukan dapat diketahui bahwa nilai kadar air tiwul instan pada berbagai persentase subtitusi ubi jalar kuning berkisar antara 4,744-7,880\% (Gambar 5). Hasil sidik ragam taraf nyata $(a \leq 0,05)$ menunjukkan bahwa variasi persentase subtitusi ubi jalar kuning pada tiwul instan berpengaruh nyata terhadap kadar air tiwul instan sehingga dilanjutkan dengan uji DNMRT.

Gambar 5 menunjukkan bahwa semakin tinggi persentase subtitusi ubi jalar kuning, akan berbanding lurus dengan nilai kadar air tiwul instan. Hal ini disebabkan oleh ubi jalar kuning memiliki kadar air tinggi, sehingga semakin tinggi persentase subtitusi ubi jalar kuning akan meningkatkan nilai kadar air tiwul instan. Menurut Suprapti (2003), kandungan air ubi jalar kuning segar

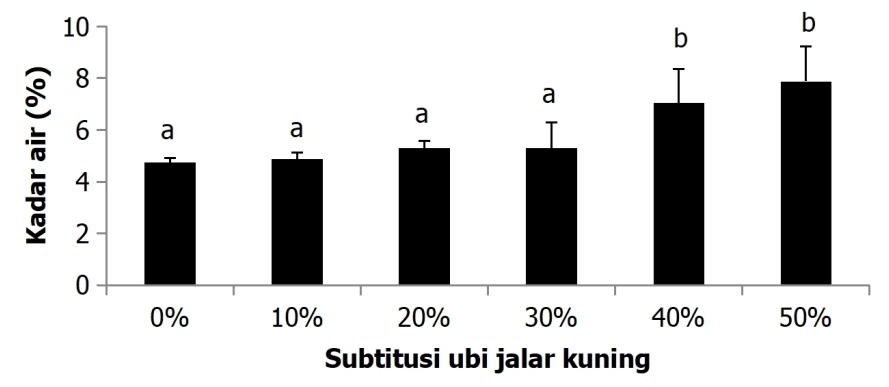

Keterangan:

Huruf yang sama pada histogram menunjukkan berbeda tidak nyata pada uji anova $(a \leq 0,05)$

Gambar 5. Grafik kadar air tiwul instan pada berbagai persentase subtitusi ubi jalar kuning

sebesar $68,50 \%$. Kadar air tiwul instan juga dipengaruhi oleh kandungan pati bahan, kandungan amilosa tepung singkong lebih tinggi yaitu 27,5\% (Murtiningrum, 2012) dibandingkan dengan kandungan amilosa ubi jalar yaitu 15-25\% (Putri, 2015), amilosa bersifat kering, kurang kuat dan higrokopis.

\section{Total $\beta$-karoten}

Berdasarkan hasil penelitian yang telah dilakukan dapat diketahui bahwa total $\beta$-karoten tiwul instan pada berbagai persentase subtitusi ubi jalar kuning berkisar antara 0,018-0,544 mg/100 g (Gambar 6). Hasil sidik ragam taraf $(a=0,05)$ menunjukkan bahwa variasi persentase subtitusi ubi jalar kuning pada tiwul instan berpengaruh nyata terhadap total $\beta$-karoten tiwul instan sehingga dilanjutkan dengan uji DNMRT.

Gambar 6 menunjukkan bahwa persentase subtitusi ubi jalar kuning kedalam tiwul instan berbanding lurus terhadap kandungan total $\beta$-karoten tiwul instan. Semakin banyak subtitusi ubi jalar kuning, maka kandungan total $\beta$-karoten juga akan semakin tinggi. Ubi jalar kuning mengandung vitamin A sebesar 7.700 SI per $100 \mathrm{~g}$ ubi jalar kuning (Suprapti, 2003). Semakin tinggi subtitusi ubi jalar kuning, semakin pekat warna kuning yang dikandung dalam bahan yang diolah, sehingga kandungan $\beta$-karoten pada produk akan semakin tinggi (Hulshof dkk., 1997).

Karetonoid dapat mengalami kerusakan pada suhu tinggi, oksidasi dan isomerisasi. Menurut Muchtadi (1992), karotenoid pada suhu $60{ }^{\circ} \mathrm{C}$ belum mengalami kerusakan, karetonoid akan mengalami kerusakan pada suhu tinggi yaitu melalui degradasi thermal sehingga terjadi dekomposisi karetonoid yang mengakibatkan turunnya intensitas warna karoten atau terjadi pemucatan warna, hal tersebut terjadi dalam kondisi oksidatif. 


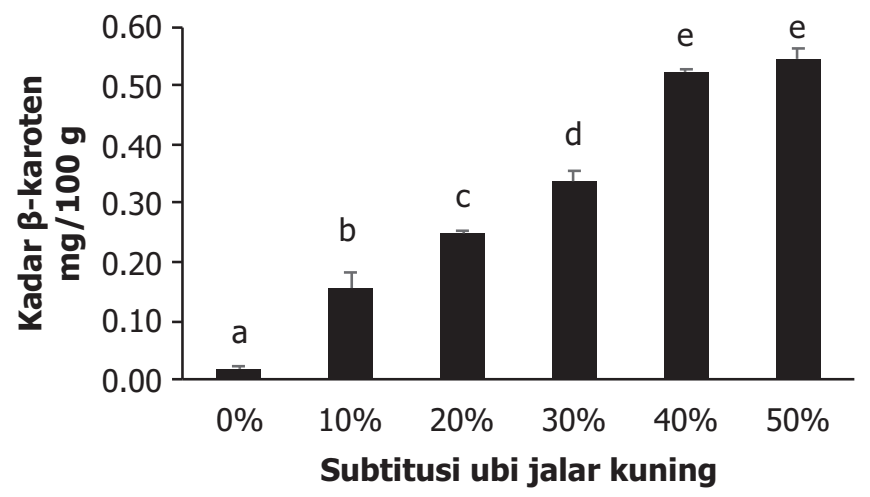

Keterangan:

Huruf yang sama pada histogram menunjukkan berbeda tidak nyata pada uji anova $(a \leq 0,05)$

Gambar 6. Grafik kadar $\beta$-karoten tiwul instan pada berbagai persentase subtitusi ubi jalar kuning

\section{Tingkat Kesukaan Warna}

Hasil uji organoleptik dengan parameter suka sangat suka menunjukkan bahwa persentase kesukaan panelis akan warna tiwul instan yang disubtitusi ubi jalar kuning berkisar antara 8 - $48 \%$ (Tabel 1 ).

Tabel 1. Persentase kesukaan warna tiwul instan yang disubtitusi bubur ubi jalar kuning

\begin{tabular}{cccc}
\hline Perlakuan & $\begin{array}{c}\text { Suka } \\
(\%)\end{array}$ & $\begin{array}{c}\text { Sangat suka } \\
(\%)\end{array}$ & $\begin{array}{c}\text { Persentase } \\
(\%)\end{array}$ \\
\hline P0 & 8 & 0 & 8 \\
P1 & 16 & 4 & 20 \\
P2 & 24 & 4 & 28 \\
P3 & 32 & 16 & 48 \\
P4 & 32 & 12 & 44 \\
P5 & 12 & 8 & 20 \\
\hline
\end{tabular}

Hasil uji chi-square untuk penilaian kesukaan warna tiwul instan subtitusi ubi jalar kuning menunjukkan bahwa variasi subtitusi ubi jalar kuning berpengaruh nyata terhadap kesukaan warna panelis terhadap warna tiwul instan. Tabel 1 menunjukkan bahwa perlakuan P3 (subtitusi ubi jalar kuning 30\%) yang paling disukai oleh panelis dengan persen kesukaan warna sebesar $48 \%$, sedangkan yang paling tidak disukai yaitu perlakuan $\mathrm{P} 1$ ( subtitusi bubur ubi jalar kuning 0\%) dengan persen kesukaan warna sebesar $8 \%$. Hal ini menunjukkan bahwa panelis menyukai tiwul instan yang warnanya kurang cerah (nilai $\mathrm{L}=60,98$ ).

Persentase subtitusi ubi jalar kuning berbanding lurus terhadap warna tiwul instan yang dihasilkan, semakin besar subtitusi ubi jalar kuning maka warna yang dihasilkan juga semakin gelap yang disebabkan oleh reaksi maillard. Reaksi maillard terjadi dengan adanya gula pereduksi dan senyawa gugus amin yang dipicu oleh adanya pemanasan, sehingga terbentuk pigmen melanoidin yang bertanggung jawab pada pembentukan warna lebih gelap (Kusnandar, 2010). Kecepatan reaksi maillard akan meningkat seiring dengan meningkatnya $\mathrm{pH}$, suhu dan kadar air (Oliveira dkk., 2014)

\section{Tingkat Kesukaan Aroma}

Hasil uji organoleptik dengan parameter suka sangat suka menunjukkan bahwa persentase kesukaan panelis akan aroma tiwul instan yang disubtitusi ubi jalar kuning berkisar antara 4 - $32 \%$ (Tabel 2).

Tabel 2. Persentase kesukaan aroma tiwul instan yang disubtitusi bubur ubi jalar kuning

\begin{tabular}{cccc}
\hline Perlakuan & $\begin{array}{c}\text { Suka } \\
(\%)\end{array}$ & $\begin{array}{c}\text { Sangat suka } \\
(\%)\end{array}$ & $\begin{array}{c}\text { Persentase } \\
(\%)\end{array}$ \\
\hline P0 & 4 & 8 & 12 \\
P1 & 0 & 4 & 4 \\
P2 & 12 & 4 & 16 \\
P3 & 16 & 8 & 24 \\
P4 & 28 & 4 & 32 \\
P5 & 28 & 4 & 32 \\
\hline
\end{tabular}

Hasil uji chi-square untuk penilaian kesukaan aroma tiwul instan subtitusi ubi jalar kuning menunjukkan bahwa variasi subtitusi ubi jalar kuning berpengaruh nyata terhadap kesukaan aroma panelis terhadap aroma tiwul instan. Tabel 2 menunjukkan bahwa perlakuan P4 dan P5 (subtitusi ubi jalar kuning $40 \%$ dan $50 \%$ ) yang paling disukai oleh panelis dengan persen kesukaan aroma sebesar $32 \%$, sedangkan yang paling tidak disukai yaitu perlakuan P1 ( subtitusi bubur ubi jalar kuning $10 \%$ ) dengan persen kesukaan warna sebesar $4 \%$. Hal ini menunjukkan bahwa panelis menyukai tiwul instan yang aromanya khas ubi jalar kuning.

Aroma khas tiwul akan semakin hilang dengan meningkatnya jumlah subtitusi ubi jalar kedalam tiwul instan yang disebabkan oleh reaksi maillard. Benyamin (2012) mengatakan reaksi maillard dapat memberikan perubahan besar pada industri makanan, sebab reaksi ini dapat mempengaruhi aroma, rasa, dan warna.

\section{Tingkat Kesukaan Rasa}

Hasil uji organoleptik dengan parameter suka sangat suka menunjukkan bahwa persentase kesukaan 
Tabel 3. Persentase kesukaan rasa tiwul instan yang disubtitusi bubur ubi jalar kuning

\begin{tabular}{cccc}
\hline Perlakuan & $\begin{array}{c}\text { Suka } \\
(\%)\end{array}$ & $\begin{array}{c}\text { Sangat suka } \\
(\%)\end{array}$ & $\begin{array}{c}\text { Persentase } \\
(\%)\end{array}$ \\
\hline P0 & 4 & 0 & 4 \\
P1 & 4 & 0 & 4 \\
P2 & 12 & 0 & 12 \\
P3 & 20 & 0 & 20 \\
P4 & 32 & 4 & 36 \\
P5 & 16 & 0 & 16 \\
\hline
\end{tabular}

panelis akan rasa tiwul instan yang disubtitusi ubi jalar kuning berkisar antara 4 - 36\% (Tabel 2).

Hasil uji chi-square untuk penilaian kesukaan rasa tiwul instan subtitusi ubi jalar kuning menunjukkan bahwa variasi subtitusi ubi jalar kuning berpengaruh nyata terhadap kesukaan rasa panelis terhadap rasa tiwul instan. Tabel 3 menunjukkan bahwa perlakuan P4 (subtitusi ubi jalar kuning 40\%) yang paling disukai oleh panelis dengan persen kesukaan rasa sebesar $36 \%$, sedangkan yang paling tidak disukai yaitu perlakuan P0 dan P1 (subtitusi bubur ubi jalar kuning 0\% dan 10\%) dengan persen kesukaan warna sebesar $4 \%$. Hal ini menunjukkan bahwa panelis menyukai tiwul instan yang rasa ubi jalar kuning cukup kuat dan ubi jalar kuning yang mengandung gula, dimana gula dapat meningkatkan cita rasa pada makanan. Akan tetapi juga akan berakibat buruk jika terlalu banyak kandungan gula pada bahan dan akan terjadi reaksi maillard yang berlebih. Reaksi maillard dapat mempengaruhi cita rasa, warna, dan aroma pada makanan (Benyamin, 2012). Menurut Parisi dkk. (2019), bahwa senyawa melanoidin yang terjadi pada reaksi maillard mengakibatkan perubahan warna kuning sampai coklat dan memberikan rasa pahit serta citarasa yang khas pada makanan, reaksi maillard tidak hanya menghasilkan flavor yang dikehendaki, tapi dapat pula membentuk flavor yang tidak dikehendaki hal tersebut dapat merusak makanan.

\section{Tingkat Kesukaan Tekstur}

Hasil uji organoleptik dengan parameter suka sangat suka menunjukkan bahwa persentase kesukaan panelis akan tekstur tiwul instan yang disubtitusi ubi jalar kuning berkisar antara 4 - 20\% (Tabel 4).

Hasil uji chi-square untuk penilaian kesukaan tekstur tiwul instan subtitusi ubi jalar kuning menunjukkan bahwa variasi subtitusi ubi jalar kuning berpengaruh nyata terhadap kesukaan tekstur panelis terhadap tekstur tiwul instan. Tabel 4 menunjukkan
Tabel 4. Persentase kesukaan tekstur tiwul instan yang disubtitusi bubur ubi jalar kuning

\begin{tabular}{cccc}
\hline Perlakuan & $\begin{array}{c}\text { Suka } \\
(\%)\end{array}$ & $\begin{array}{c}\text { Sangat suka } \\
(\%)\end{array}$ & $\begin{array}{c}\text { Persentase } \\
(\%)\end{array}$ \\
\hline P0 & 20 & 0 & 20 \\
P1 & 16 & 4 & 20 \\
P2 & 8 & 0 & 8 \\
P3 & 0 & 4 & 4 \\
P4 & 8 & 0 & 8 \\
P5 & 8 & 8 & 16 \\
\hline
\end{tabular}

bahwa perlakuan P0 dan P1 (subtitusi ubi jalar kuning $0 \%$ dan $10 \%$ ) yang paling disukai oleh panelis dengan persen kesukaan tekstur sebesar 20\%, sedangkan yang paling tidak disukai yaitu perlakuan P3( subtitusi bubur ubi jalar kuning 30\%) dengan persen kesukaan warna sebesar $4 \%$. Hal ini menunjukkan bahwa panelis menyukai tiwul instan yang teksturnya remah.

Semakin tinggi subtitusi ubi jalar kuning, maka kandungan air bahan akan semakin tinggi, kandungan air ubi jalar kuning segar sebesar $68 \%$ per $100 \mathrm{~g}$ bahan (Suprapti, 2003). Kandungan air pada ubi jalar akan mempengaruhi tekstur yang dihasilkan. Adanya pati pada bahan yang bereaksi dengan air mengakibatkan tekstur tiwul instan menjadi lebih keras, namun pati hanya mampu mengikat air hingga volume hidratasi maksimum yang dapat dicapai oleh granula pati (Swinkels \& Veendams, 1985). Kandungan amilosa tepung singkong lebih tinggi yaitu 27,5\% (Murtiningrum, 2012) dibandingkan dengan kandungan amilosa ubi jalar yaitu $15-25 \%$ (Putri, 2015), semakin tinggi kandungan amilosa maka tiwul instan akan bersifat kering, sehingga mempunyai tekstur remah.

\section{Tingkat Kesukaan Kekenyalan}

Hasil uji organoleptik dengan parameter suka sangat suka menunjukkan bahwa persentase kesukaan panelis akan kekenyalan tiwul instan yang disubtitusi ubi jalar kuning berkisar antara 0 - 32\% (Tabel 5).

Hasil uji chi-square untuk penilaian kesukaan kekenyalan tiwul instan subtitusi ubi jalar kuning menunjukkan bahwa variasi subtitusi ubi jalar kuning berpengaruh nyata terhadap kesukaan kekenyalan panelis terhadap kekenyalan tiwul instan. Tabel 5 menunjukkan bahwa perlakuan P3 (subtitusi ubi jalar kuning $30 \%$ ) yang paling disukai oleh panelis dengan persen kesukaan aroma sebesar 32\%, sedangkan yang paling tidak disukai yaitu perlakuan PO ( subtitusi bubur ubi jalar kuning $0 \%$ ) dengan persen kesukaan 
Tabel 5. Persentase kesukaan kekenyalan tiwul instan yang disubtitusi bubur ubi jalar kuning

\begin{tabular}{cccc}
\hline Perlakuan & $\begin{array}{c}\text { Suka } \\
(\%)\end{array}$ & $\begin{array}{c}\text { Sangat suka } \\
(\%)\end{array}$ & $\begin{array}{c}\text { Persentase } \\
(\%)\end{array}$ \\
\hline P0 & 0 & 0 & 0 \\
P1 & 16 & 0 & 16 \\
P2 & 16 & 0 & 16 \\
P3 & 24 & 8 & 32 \\
P4 & 20 & 8 & 28 \\
P5 & 4 & 12 & 16 \\
\hline
\end{tabular}

kekenyalan sebesar $0 \%$. Hal ini menunjukkan bahwa panelis menyukai tiwul instan yang kekenyalannya sedang.

Tingkat kekenyalan tiwul instan dipengaruhi oleh kandungan amilopektin pada bahan. Kandungan amilopektin tepung singkong lebih tinggi $72,62 \%$ dibandingkan dengan kandungan amilosanya yaitu 27,38\% (Murtiningrum, 2012). Kekenyalan pada tiwul instan juga disebabkan oleh kandungan pati, tiwul instan akan mengembang hingga mencapai volume hidrasi maksimum yang dapat dicapai (Swinkels \& Veendams, 1985).

\section{Tingkat Kesukaan Keseluruhan}

Hasil uji organoleptik dengan parameter suka sangat suka menunjukkan bahwa persentase kesukaan panelis akan kesukaan keseluruhan tiwul instan yang disubtitusi ubi jalar kuning berkisar antara 0 - $32 \%$ (Tabel 6).

Tabel 6. Persentase kesukaan keseluruhan tiwul instan yang disubtitusi bubur ubi jalar kuning

\begin{tabular}{cccc}
\hline Perlakuan & $\begin{array}{c}\text { Suka } \\
(\%)\end{array}$ & $\begin{array}{c}\text { Sangat suka } \\
(\%)\end{array}$ & $\begin{array}{c}\text { Persentase } \\
(\%)\end{array}$ \\
\hline P0 & 0 & 0 & 0 \\
P1 & 8 & 0 & 8 \\
P2 & 16 & 0 & 16 \\
P3 & 32 & 12 & 44 \\
P4 & 28 & 16 & 44 \\
P5 & 8 & 8 & 16 \\
\hline
\end{tabular}

Hasil uji chi-square untuk penilaian kesukaan keseluruhan tiwul instan subtitusi ubi jalar kuning menunjukkan bahwa persentase subtitusi ubi jalar kuning berpengaruh nyata terhadap kesukaan keseluruhan panelis terhadap tiwul instan. Tabel 6 menunjukkan bahwa perlakuan P3 dan P4 (subtitusi ubi jalar kuning $30 \%$ dan $40 \%$ ) yang paling disukai oleh panelis dengan persen kesukaan keseluruhan sebesar $44 \%$, sedangkan yang paling tidak disukai yaitu perlakuan PO ( subtitusi bubur ubi jalar kuning 0\%) dengan persen kesukaan warna sebesar $0 \%$. Hal ini menunjukkan bahwa panelis menyukai tiwul instan dengan persentase subtitusi ubi jalar kuning kategori sedang.

Kesukaan keseluruhan tiwul instan lebih ditentukan oleh kesukaan warna, aroma, tekstur, rasa dan kekenyalan. Semakin besar subtitusi ubi jalar kuning pada tiwul instan maka perubahan yang terjadi akan semakin besar, dapat dilihat dari warna, rasa, aroma, tekstur, dan kekenyalan tiwul instan yang dihasilkan. Winarno (2007), mengatakan berbagai macam cara yang dapat dilakukan untuk menganalisis secara objektif bahan makanan untuk mengetahui penurunan mutu, akan tetapi penentuan nilai akhir adalah kepuasan panelis.

\section{Uji Efektivitas}

Pengujian tiwul instan terbaik menggunakan uji efektivitas, uji ini dilakukan untuk mengetahui perlakuan terbaik berdasarkan beberapa parameter pengamatan yang telah diuji. Nilai efektivitas tiwul instan dengan subtitusi ubi jalar kuning yang diperoleh dapat dilihat pada Tabel 7.

Rabel 7. Nilai efektivitas tiwul instan berdasarakan persentase subtitusi ubi jalar kuning.

\begin{tabular}{ccc}
\hline Sampel & $\begin{array}{c}\text { Subtitusi ubi jalar } \\
\text { kuning }\end{array}$ & Nilai efektivitas \\
\hline P0 & $0 \%$ & 0.08 \\
P1 & $10 \%$ & 0.16 \\
P2 & $20 \%$ & 0.44 \\
P3 & $30 \%$ & 0.88 \\
P4 & $40 \%$ & 0.84 \\
P5 & $50 \%$ & 0.44 \\
\hline
\end{tabular}

Berdasarkan Tabel 7 dapat diketahui bahwa nilai hasil uji efektivitas tiwul instan dengan subtitusi ubi jalar kuning berkisar antara 0,08 sampai dengan 0,88. Nilai efektivitas tertinggi terdapat pada perlakuan subtitusi ubi jalar kuning P3 (subtitusi ubi jalar kuning $30 \%$ ), sedangkan nilai efektivitas terendah terdapat pada perlakuan PO (subtitusi ubi jalar kuning 0\%). Nilai efektivitas yang tinggi menunjukkan bahwa perlakuan tersebut adalah perlakuan terbaik dari 
keseluruhan perlakuan yang dilakukan. Perlakuan ini memiliki karakteristik daya rehidrasi $4,31 \%$; densitas kamba 0,417 g/mL; daya kembang 37,33\%; kadar air 5,31\%; kadar $\beta$-karoten 0,62 mg/100 g; dan persentase kesukaan warna $48 \%$; kesukaan aroma $24 \%$, kesukaan rasa 20\%; kesukaan tekstur $4 \%$, kesukaan kekenyalan $32 \%$, dan kesukaan keseluruhan $44 \%$.

\section{KESIMPULAN}

Berdasarkan penelitian yang telah dilakukan dapat disimpulkan bahwa peningkatan persentase subtitusi ubi jalar kuning menyebabkan peningkatan kadar air dan total $\beta$-karoten tiwul instan, namun menyebabkan penurunan daya rehidrasi, daya kembang, densitas kamba dan kecerahan tiwul instan yang dihasilkan. Berdasarkan uji efektivitas didapatkan perlakuan terbaik pada pembuatan tiwul instan adalah persentase subtitusi ubi jalar kuning sebesar $30 \%$, dengan memiliki karakteristik daya rehidrasi 4,31\%; densitas kamba $0,417 \mathrm{~g} / \mathrm{mL}$; daya kembang 37,33\%; kadar air 5,31\%; kadar $\beta$-karoten $0,336 \mathrm{mg} / 100 \mathrm{~g}$; dan persentase kesukaan warna $48 \%$; kesukaan aroma $24 \%$, kesukaan rasa $20 \%$; kesukaan tekstur $4 \%$, kesukaan kekenyalan $32 \%$, dan kesukaan keseluruhan $44 \%$.

\section{UCAPAN TERIMA KASIH}

Ucapan terima kasih terutama ditujukan kepada IDB (Islamic Development Bank) melalui Konsorsium Food Security 4 in 1 IDB Project yang telah membiayai penelitian ini dan LP2M Universitas Jember yang telah memberikan kesempatan dan fasilitas perijinan sehigga penelitian ini dapat terlaksana dengan baik.

\section{KONFLIK KEPENTINGAN}

Penulis menyatakan bahwa tidak ada konflik kepentingan dari berbagai pihak pada penelitian ini.

\section{DAFTAR PUSTAKA}

Almatsier, S. (2010). Prinsip Dasar IImu Gizi. Jakarta: Gramedia Pustaka Utama.

AOAC. (2007). Official methods of analysis. 18th Edition, Associations of Analytical Chemists, International, Washington DC.

Badan Penelitian dan Pengembangan Kesehatan. (2010). Laporan riskesdas 2010. KEMENTERIAN KESEHATAN RI. Retrieved from http://www.academia.edu/10119285/ Laporan_riskesdas_2010.
Badan Pusat Statistik. (2016). Produksi dan Luas Tanaman Singkong di Indonesia. Badan Pusat Statistik Indonesia. Jakarta.

BALITKABI. (2011). Deskripsi Varietas Unggul Kacangkacangan dan Ubi-ubian. Malang: Agro inovasi.

Bemiller, JN. \& Whistler, RL. (1996). Carbohydrates in Food Chemistry. O. R. Fennema (ed.). New York: Marcel Dekker Inc.

Benyamin, KS. (2012). Food Biochemistry and Food Processing, $2^{\text {nd }}(\mathrm{ed})$. John Wiley \& Sons, Inc. New York. DOI: $10.1002 / 9781118035$

Bradbury, J. H., \& Nixon, R. W. (1998). The acridity of raphides from the edible aroids. Journal of the Science of Food and Agriculture, 76(4), 608-616. https://doi. org/10.1002/(SICI)1097-0010(199804)76:4<608::AIDJSFA996 > 3.0.CO;2-2

DeGarmo, E. P., Sullivan, W. G., \& Canada, J. R. (1984). Engineering economy (7th ed). New York : Macmillan; London: Collier Macmillan. Retrieved from https:// trove.nla.gov.au/version/32750478

Dwiyanti, G., Siswaningsih, W., \& Febrianti, A. (2018). Production of purple sweet potato ( Ipomoea batatas L.) juice having high anthocyanin content and antioxidant activity. Journal of Physics: Conference Series, 1013(1), 012194. https://doi.org/10.1088/17426596/1013/1/012194

Dziedzic, S. Z., \& Kearsley, M. W. (1995). Handbook of Starch Hydrolysis Products and their Derivatives. Springer US. Retrieved from //www.springer.com/gp/ book/9780751402698

Harada, K., Kano, M., Takayanagi, T., Yamakawa, O., \& Ishikawa, F. (2004). Absorption of Acylated Anthocyanins in Rats and Humans after Ingesting an Extract of Ipomoea batatas Purple Sweet Potato Tuber. Bioscience, Biotechnology, and Biochemistry, 68(7), 1500-1507. https://doi.org/10.1271/bbb.68.1500

Hartati, N. S., \& Prana, T. K. (2003). Analisis Kadar Pati dan Serat Kasar Tepungbeberapa Kultivar Talas ( Colocasia esculenta L. Schott). Jurnal Natur Indonesia, 6(1), 2933.

Heldman, D. R. \& Singh, P. R. (1981). Food Proses Enginering. $2^{\text {nd }}$ ed. The AVI Publ. Comp., Inc. Westrop. CT, USA

Hidayat, N., \& Saati, E. A. (2006). Membuat Pewarna Alami. Trubus Agrisarana. Surabaya.

Hulshof, P. J. M., Xu, C., van de Bovenkamp, P., Muhilal, \& West, C. E. (1997). Application of a Validated Method for the Determination of Provitamin A Carotenoids in Indonesian Foods of Different Maturity and Origin. Journal of Agricultural and Food Chemistry, 45(4), 1174-1179. https://doi.org/10.1021/jf9603137 
Kano, M., Takayanagi, T., Harada, K., Makino, K., \& Ishikawa, F. (2005). Antioxidative Activity of Anthocyanins from Purple Sweet Potato, Ipomoera batatas Cultivar Ayamurasaki. Bioscience, Biotechnology, and Biochemistry, 69(5), 979-988. https://doi.org/10.1271/bbb.69.979

Kusnandar, F. (2010). Teknologi Modifikasi Pati dan Aplikasinya di Industri Pangan. Retrieved August 20, 2018, from http://itp.fateta.ipb.ac.id/id/index2.php?option=com_ content\&do_pdf $=1 \& i d=111$

León, K., Mery, D., Pedreschi, F., \& León, J. (2006). Color measurement in $\mathrm{L} * \mathrm{a} * \mathrm{~b} *$ units from RGB digital images. Food Research International, 39, 1084-1091. https:// doi.org/10.1016/j.foodres.2006.03.006

Lindawati, L. (1992). Mempelajari Cara Pembuatan Minuman Bubuk Jambu Biji (Psidium guajava L). Retrieved from http://repository.ipb.ac.id/xmlui/ handle/123456789/30930

Mabesa, L. B. (1986). Sensory Evaluation of Foods: Principles and Methods. Laguna: COLLEGE OF AGRICULTURAL University of the Philippines at Los Baños College.

Moorthy, S. (2004). Tropical sources of starch. In Starch in Food: Structure, Function and Applications (pp. 321359). https://doi.org/10.1533/9781855739093.2.321

Muchtadi, T. R. (1992). Karakterisasi komponen intrinsik utama buah sawit (Elaeis guineensis, Jacq.) dalam rangka optimalisasi proses ekstraksi minyak dan pemanfaatan provitamin A. Retrieved from http://repository.ipb.ac.id/ xmlui/handle/123456789/23199

Murtiningrum, M., Lisangan, M. M., \& Edoway, Y. (2016). Pengaruh Preparasi Ubi Jalar (Ipomoea Batatas L.) Sebagai Bahan Pengental Terhadap Komposisi Kimia Dan Sifat Organoleptik Saus Buah Merah (Pandanus Conoideus L.). Agrointek, 6(1), 1-7.

Oliveira, F. C. D., Coimbra J. S. D. R., de Oliveira E. B., Zuñiga A. D. G., \& Rojas E. E. G. (2014). Food ProteinPolysaccharide Conjugates obtained via the Maillard Reaction: A Review. Crit Rev Food Sci Nutr. 13:37-41.

Parisi, S., Sara, M.A., Shana, M. \& Anna, S. (2019). Maiilard Reaction in Foods Mitigation Strategies and Positive properties. Springer. Swizerland. https://doi. org/10.1007/978-3-03022556-8

Pujimulyani, D., \& Wazyka, A. (2009). Antioxidation, chemical, and physical propesties of wet sweets from white Saffron (Curcuma mangga Val.). Agritech, 29(3), 167-173.

Putri, A. M. E. (2015). Modifikasi Pati Ubi Jalar Putih (Ipomoea batatas L.) Menggunakan Enzim Amylomaltase menjadi PatiThermoreversible (Kajian Lama Inkubasi dan Konsentrasi Enzim Amylomaltase) (Sarjana). Universitas Brawijaya. Retrieved from http://repository.ub.ac. id/149691/
Putri, N.A., Herlina H., \& Subagio, A. (2018). Karakterisrtik Mocaf (Modified Cassava Flour) Berdasarkan Metode Penggilingan dan Lama Fermentasi. Jurnal Agroteknologi, 12(1), 79-89.

Romlah, \& Haryadi. (1997). Sifat fisik adonan dan mie beberapa jenis tepung gandum dengan variasi penambahan kansui, telur dan tepung ubi kayu (Thesis). [Yogyakarta]: Universitas Gadjah Mada. Retrieved from. http://etd. ugm.ac.id/index.php?mod=penelitian_detail \&sub= PenelitianDetail\&act=view\&typ=html\&buku_id $=18535$

Rukmini, H.S., \& Naufalin, R. (2015). Formulasi Tiwul Instan Tinggi Protein Melalui Penambahan Lembaga Serealia dan Konsentrat Protein Kedelai. Jurnal Teknologi Industri Pertanian. 25(3): 190-197.

Simpson, B. K. (Ed.). (2012). Food Biochemistry and Food Processing. In Food Biochemistry and Food Processing (2nd ed., pp. i-xii). New York: John Wiley \& Sons, Ltd. https://doi.org/10.1002/9781118308035.fmatter

Soetanto, N. . (2008). Tepung Kasava dan Olahannya. Yogyakarta: Kanisius.

Subagio, A. (2006). Ubi Kayu Subtitusi Berbagai Tepungtepungan. Food Review. 1(3). 18-22.

Suda, I., Oki, T., Masuda, M., Kobayashi, M., Nishiba, Y., \& Furuta, S. (2003). Physiological Functionality of PurpleFleshed Sweet Potatoes Containing Anthocyanins and Their Utilization in Foods. Japan Agricultural Research Quarterly: JARQ, 37(3), 167-173. https://doi. org/10.6090/jarq.37.167

Suprapti, M. L. (2003). Tepung Ubi Jalar: Pembuatan dan Pemanfaatannya (1st ed., Vol. 1). Yogyakarta: Kanisius.

Swinkels \& Veendanm. (1985). Composition and Properties of Commercial Native Starches. Starch - Stärke, 37 (1), 1-5. https://doi.org/10.1002/star.19850370102

Syarief, R., \& Halid, H. (1993). Teknologi penyimpanan pangan. Arcan. Jakarta.

Thompson, J., Manore, M., \& Vaughan, L. A. (2011). The science of nutrition (2nd ed., Student ed). San Francisco, CA: Pearson Benjamin Cummings.

Winarno, F. G. (2007). Kimia Pangan dan gizi (11th ed.). Jakarta: P.T. Gramedia.

Yoshimoto, M., Okuno, S., Yamaguchi, M., \& Yamakawa, O. (2001). Antimutagenicity of Deacylated Anthocyanins in Purple-fleshed Sweetpotato. Bioscience, Biotechnology, and Biochemistry, 65(7), 1652-1655. https://doi. org/10.1271/bbb.65.1652 